\title{
Maullinia ectocarpii gen. et sp. nov. (Plasmodiophorea), an Intracellular Parasite in Ectocarpus siliculosus (Ectocarpales, Phaeophyceae) and other Filamentous B rown Algae
}

\author{
Ingo Maiera,1, Elisa Parodib, Renato Westermeierc, and Dieter G. Müller \\ a Fachbereich Biologie, Universität Konstanz, D-78457 Konstanz, Germany \\ b Instituto Argentino de Oceanografía, UNS-CONICET, 8000 Bahia Blanca, Argentina \\ c Facultad de Pesquerias y Oceanografia, Universidad Austral de Chile, Casilla 1327, Puerto Montt, Chile
}

An obligate intracellular parasite infecting Ectocarpus spp. and other filamentous marine brown algae is described. The pathogen forms an unwalled multinucleate syncytium (plasmodium) within the host cell cytoplasm and causes hypertrophy. Cruciform nuclear divisions occur during early development. Mature plasmodia become transformed into single sporangia, filling the host cell completely, and then cleave into several hundred spores. The spores are motile with two unequal, whiplash-type flagella inserted subapically and also show amoeboid movement. Upon settlement, cysts with chitinous walls are formed. Infection of host cells is accomplished by means of an adhesorium and a stachel apparatus penetrating the host cell wall, and injection of the cyst content into the host cell cytoplasm. The parasite is characterized by features specific for the plasmodiophorids and is described as a new genus and species, Maullinia ectocarpii.

\section{Introduction}

Filamentous brown algae are important members in many benthic marine communities. They have been frequently reported to be attacked by various pathogens, including viruses (Müller et al. 1998) and eukaryotic parasites of different phylogenetic lineages: oomycetes, chytrids and hyphochytrids (Andrews 1976; Küpper and Müller 1999; Müller et al. 1999; Porter 1986; Sparrow 1960). Although there is good reason to speculate that, besides herbivory, parasitism may play an important role in the population dynamics, few laboratory studies have been

\footnotetext{
${ }^{1}$ Corresponding author;
}

fax 497531882966

e-mail Ingo.Maier@uni-konstanz.de made on living algal hosts and their parasites. As has been stated by Andrews (1976), "pathological investigations by algologists have been more the result of coincidence than design".

During a study on algal epiphytes on a mariculture plantation in Chile, we encountered specimens of the marine brown alga Ectocarpus siliculosus (Dillwyn) Lyngbye which displayed symptoms of infection by a parasite of unknown identity. We report here our observations on field and cultured material which show that the pathogen is a new taxon in the Plasmodiophorea with a potentially wide host range within the brown algae. The Plasmodiophorea have recently been included into the Protoctista (Dylewski $1990)$ or into the kingdom Protozoa (Protista) (Barr 
1992; Braselton 1995; Cavalier-Smith 1993a, b; Corliss 1994). Small subunit rRNA gene sequence comparison of Plasmodiophora brassicae Woronin (Castlebury and Domier 1998) also corroborates placement among the protists, with no close relationship to true fungi, Mycetozoa, Rhizopoda, or Chromista. Here we follow Buczacki (1983) and Braselton (1995) in using the informal term "plasmodiophorids" which does not imply a certain taxonomic rank. The group includes obligate endoparasites of higher plants, algae and oomycetes. During its trophic phases, the thallus occurs as an unwalled, syncytical protoplast referred to as a plasmodium. Eventually it develops into a sporangium or a sporosorus composed of aggregates of resting spores. The terminology used here in respect to the life cycle corresponds to that suggested by Karling (1981) and Braselton (1995).

\section{Results}

\section{Field Material}

The majority of E. siliculosus filaments collected at La Pasada, Chile, appeared morphologically normal and formed plurilocular zoidangia. The habit of the thalli and the occasional presence of unilocular sporangia indicated that they were sporophytes. About $15 \%$ of the samples were sterile and showed abortive sporangia characteristic for viral infection (Müller et al. 1998). A still smaller proportion of thalli (about 1\%) formed few plurilocular sporangia, but also clusters of relatively large lateral appendages along the filament axes (Figs. 1, 2). These oblong to sub-spherical vesicles were mostly free of pigments. They were predominantly found sessile on filament cells or on terminal cells of the main axis and lateral branches of the thallus, rarely intercalary. Release of numerous non-pigmented zoospores from apical openings showed the parasitic, sporangial nature of the observed structures. Intense screening of field material revealed several cases where symptoms of virus infection co-existed with parasite sporangia on the same host filament. The parasite has also been identified on a microslide prepared of $E$. siliculosus collected at Flinders, Westport Bay, Victoria, Australia in September 1988. At that time, release of zoospores had been recorded, but no further studies were carried out.

\section{Establishment of Laboratory Cultures}

In a host-parasite co-culture established from selected field material, Ectocarpus reproduced pro- fusely by spores from plurilocular sporangia and tended to overgrow the parasite. Intense attention was necessary to maintain the parasite in culture. Therefore, we started a first infection experiment using, as a new host, a cultured strain of E. fasciculatus Harvey which was completely sterile due to a systemic virus infection. Filaments of the material were incubated with selected parasite sporangia from the raw culture. Within several weeks, the parasite appeared on the new host. This new hostpathogen system was stable and therefore chosen for major parts of further work. It was successively improved by elimination of all contaminants until it arrived at a triphasic state consisting of the host $E$. fasciculatus carrying its latent virus and the parasite.

\section{Development and Structure of the Parasite}

The parasite propagated and new infections were established by zoospores (Figs. 3, 4), which were produced in large numbers. They were pyriform, $4.6 \pm 0.7 \mu \mathrm{m}$ in length and $2.3 \pm 0.4 \mu \mathrm{m}$ in diameter. The two unequal, whiplash-type flagella are inserted subapically on the broader part of the cell. The long flagellum $(19.3 \pm 1.7 \mu \mathrm{m})$ undergoes undulating movement and is oriented backward, whereas the short flagellum $(8.2 \pm 0.6 \mu \mathrm{m})$ points forward at an oblique angle to the cell axis. Both flagella possess short hairtips. At some time after release and upon contact with a surface, the spores showed amoeboid movement by means of lobose pseudopodia of variable shape,which were rapidly extended and withdrawn (Figs. 5-8). Often, flagella were still present at this stage. After settlement, the cell encysted and assumed an ellipsoid to kidney-shaped morphology. Cysts were $5.8 \pm 0.7 \mu \mathrm{m}$ in length and $2.5 \pm 0.2 \mu \mathrm{m}$ in diameter.

Eventually, a pointed, "beak"- or "stiletto"-shaped infection apparatus ("adhesorium", Aist \& Williams 1971; Keskin and Fuchs 1969) was formed at one end of the cell (Figs. 9-11). The adhesorium is 5-7 $\mu \mathrm{m}$ long and 0.8-1.2 $\mu \mathrm{m}$ in diameter. It is connected to the cell body by a narrow neck portion of about $0.8 \mu \mathrm{m}$ in length. The cysts become attached to the host cell wall by the tip of the adhesorium, while the cell body is lifted off the algal filament. In microscopic preparations, the cells easily became detached. Spores retained in sporangia also encysted and produced adhesoria, as well as spores trapped in mucilage at the aperture of sporangia, adhering to a parasite sporangium or settled onto glass cover slips without contact to host cells (Fig. 13). At the tip of adhesoria attached to coverslips, minute hairpoint filaments of 1.2-1.4 $\mu \mathrm{m}$ in length or occasionally a tuft of small projections have been 

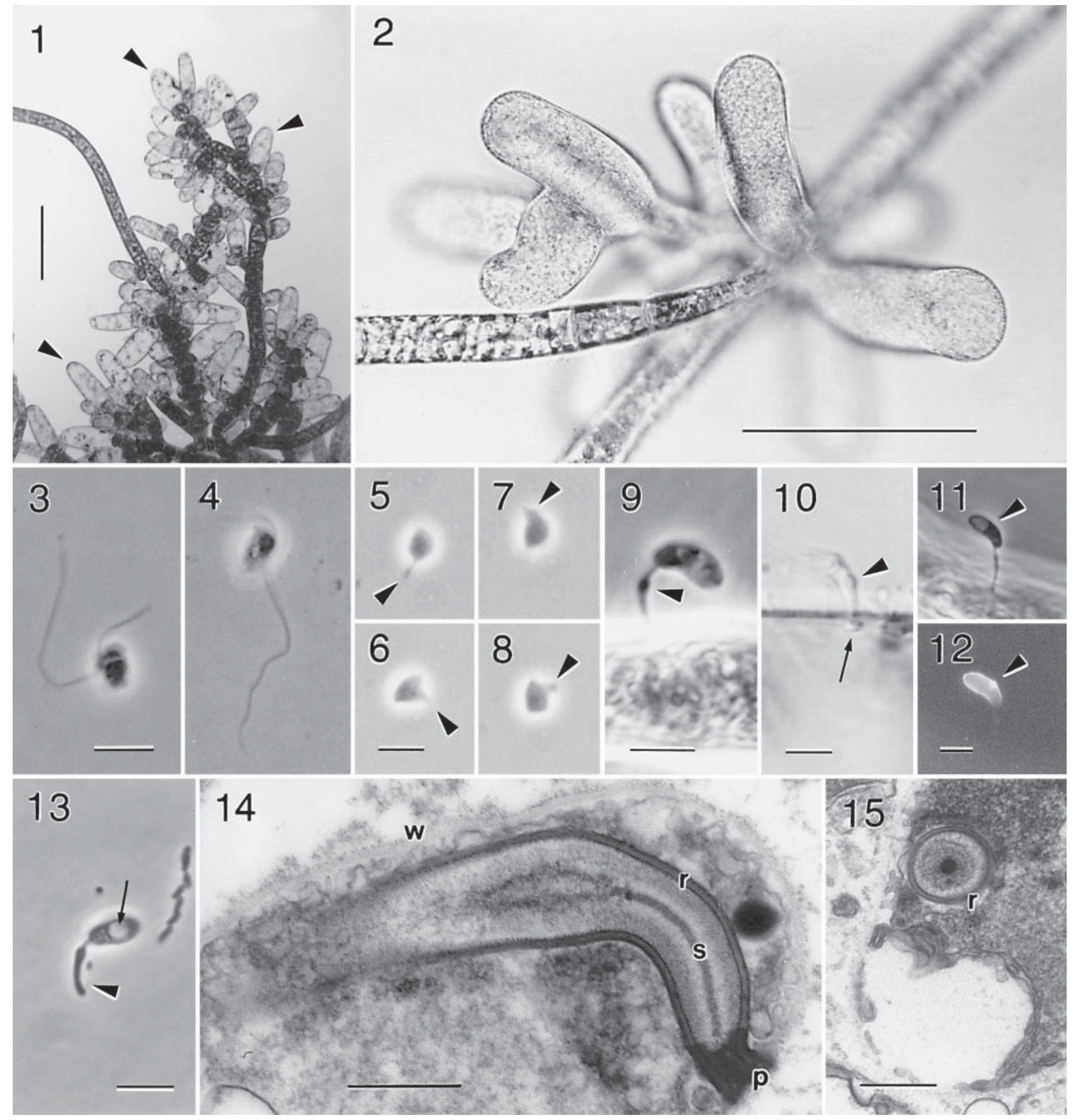

Figure 1. Filaments of E. siliculosus infected by Maullinia ectocarpii. Parasitized cells appear as pale, hypertrophied lateral appendages (arrowheads). Scale bar $=100 \mu \mathrm{m}$.

Figure 2. Group of infected cells at higher magnification. Scale bar $=100 \mu \mathrm{m}$.

Figures 3 and 4. Zoospores of Maullinia fixed in OsO4 vapour. Phase contrast. Scale bar $=5 \mu \mathrm{m}$.

Figures 5-8. Spore showing amoeboid movement with pseudopodia (arrowheads) on a glass slide. Microflash exposures taken within a few seconds. Scale bar $=5 \mu \mathrm{m}$.

Figure 9 and 10. Cysts with adhesorium (arrowhead) attached to a host filament and injecting its cytoplasmic content (arrow). Scale bars $=5 \mu \mathrm{m}$.

Figures 11-12. Fluorescent chitin labeling of cyst wall (arrowhead). Scale bar $=5 \mu \mathrm{m}$.

Figure 13. Cyst with adhesorium on coverslip, enlarged vacuole (arrow) and hairpoint tip on adhesorium (arrowhead). Scale bar $=5 \mu \mathrm{m}$.

Figures 14 and 15. Electron micrographs of adhesoria in cysts before extrusion in longitudinal and cross-section, showing the Rohr (r), Stachel (s), plug (p), and cyst wall (w). Scale bars $=0.5 \mu \mathrm{m}$. 


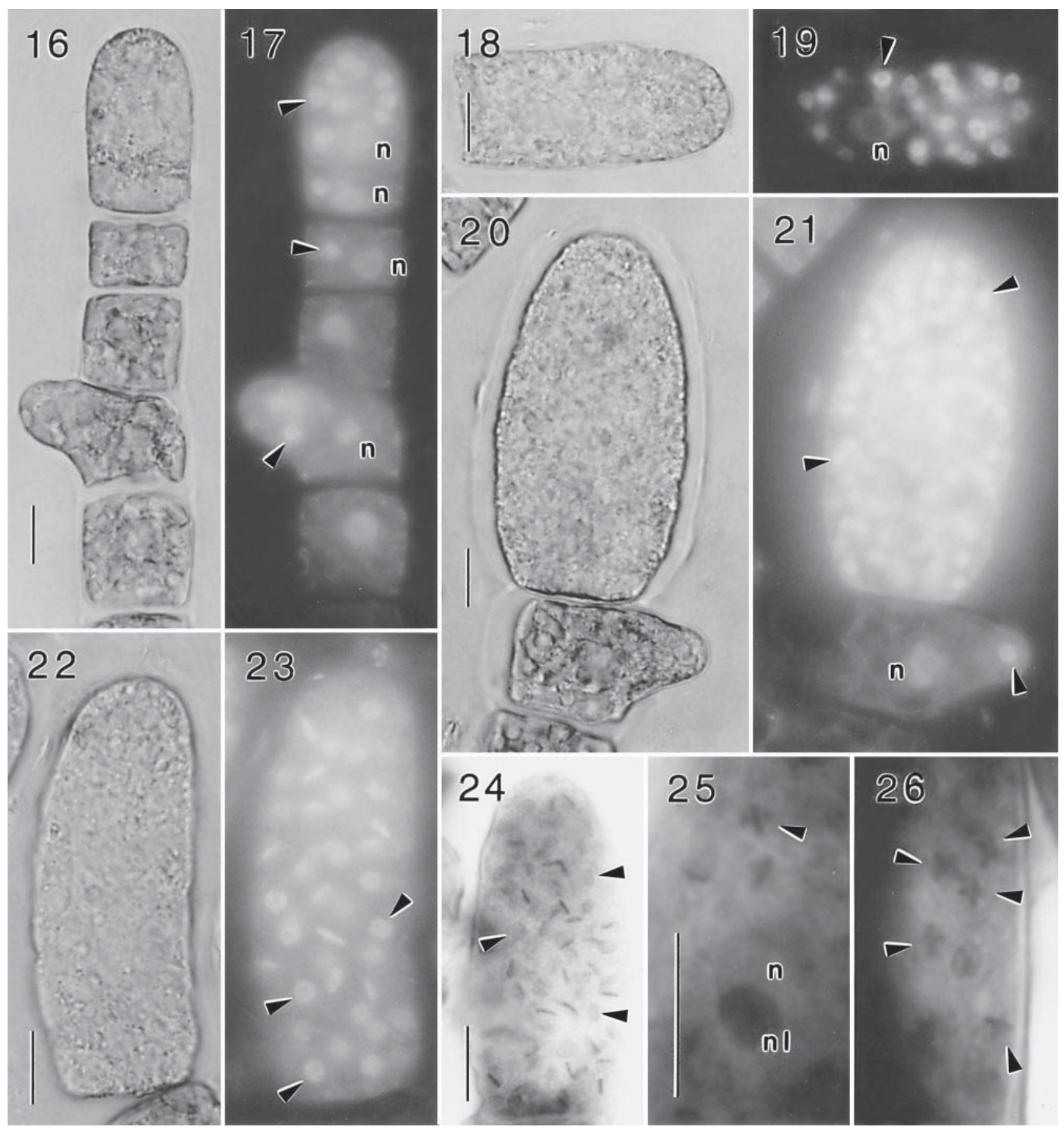

Figures 16 and 17. Early infection stages of M. ectocarpii in E. siliculosus, with parasite (arrowheads) and host nuclei (n) visualized by DAPI staining. The plasmodia contain from one to several nuclei in interphase. Scale bar $=10 \mu \mathrm{m}$.

Figures 18 and 19. A later stage of development, showing host nucleus (n) and plasmodium with many parasite nuclei in interphase (arrowheads). Scale bar $=10 \mu \mathrm{m}$.

Figures 20 and 21. Late stage in plasmodium development with numerous parasite nuclei in interphase (arrowheads). Below a freshly infected cell with a single parasite nucleus (arrowhead) and a host cell nucleus (n). Scale bar $=10 \mu \mathrm{m}$.

Figures 22 and 23. Metaphase plates in plasmodium, with chromosomes in a circular arrangement, leaving a hole in the center (arrowheads), DAPI staining. Scale bar $=10 \mu \mathrm{m}$.

Figure 24. As Figs. 22 and 23, haematoxylin staining. Scale bar $=10 \mu \mathrm{m}$.

Figures 25 and 26. Cruciform metaphase configurations (arrowheads) in young plasmodia stained by haematoxylin, with host cell nucleus $(n)$ containing a prominent nucleolus ( $n l)$. Scale bar $=10 \mu \mathrm{m}$. 
observed, possibly representing adhesive material (Fig. 13). The cyst wall showed a positive staining reaction for chitin, whereas the adhesorium was not labeled (Figs. 11, 12). Electron microscopy on cysts prior to adhesorium formation revealed a conspicuous tubular cavity, which is bound to the cytoplasm by a strongly contrasted double membrane (not shown). The end of the cavity extending through the cyst wall is occluded by an electron-dense plug. Within the cavity, wall-like material is layered directly onto the membrane. On the inner side this material is limited by a fibrillar, darkly stained layer. A dense rod-like structure of circular cross-section surrounded by fibrillar material extends along the centre (Figs. 14, 15). Upon zoospore encystment and subsequent formation of the adhesorium, the host cell wall is penetrated and the cyst content is injected into the host cell cytoplasm, accompanied by dilatation of the adhesorium (Fig. 10). The cyst becomes completely evacuated. Extrusion of the cytoplasmic content occurred only in cysts settled on host cells. Cysts having extended adhesoria on a glass surface contained a conspicuous, large vacuole (Fig. 13). These cells did not develop further. Following infection, synchronous nuclear divisions in the parasite resulted in the formation of multinucleate syncytia (plasmodia) within the host cell cytoplasm. At an early developmental stage, plasmodia were in a peripheral position without close association with the host nucleus. Occasionally, two host nuclei have been observed in infected cells. The parasite induced localized growth in the host cell (Figs. 16, 17 and 20, 21). The plasmodium gradually occupied the whole host cell, which eventually became strongly hypertrophied (Figs. 20, 21 and 35, 36). Usually, the host cell nucleus did not divide but appeared enlarged and clearly visible (Figs. 17, 19, 25) until the cell became completely filled by a plasmodium containing numerous parasite nuclei. Metaphase plates stained with DAPI or haematoxylin generally appeared doughnut-shaped, with a hole in the centre (Figs. 23, 24). In very rare instances, "cruciform nuclear divisions" of the plasmodiophorid-type have been observed in haematoxylin-stained material (Figs. 25, 26) where nucleoli are visible. In this type of mitotic division, a persistent nucleolus is elongated perpendicular to the metaphase plate of chromosomes (Braselton et al. 1975; Dylewski et al. 1978; Keskin 1971). Cruciform divisions were synchronous and occurred at a young, but already multinucleate stage. In the majority of similar plasmodia only non-cruciform mitoses (Figs. 23, 24) were found.

The host-parasite boundary was strongly stained, about 7-10 nm thick and had the appearance of a thickened unit membrane (Figs. 27-29). The plasmodia were always completely surrounded by host cell cytoplasm. They were reticulate or formed numerous filiform lobes, resulting in a large contact area between host and parasite (Fig. 27). Amoeboid movement and schizogony of plasmodia were not observed. Plasmodia contained vacuoles with fibrillar contents, but no large central cavity or food vacuoles. Host chloroplasts were not ingested by the parasite. Plasmodial nuclei were spherical and contained one prominent, centric nucleolus each. Centrioles were paired end-to-end at an angle of $180^{\circ}$ (Fig. 30). Parasite development mostly occurred in somatic host cells, but some cases of sporangium initials were seen with concomitant parasite development and virus formation in the same host cell. The fate of these products is unknown.

Mature plasmodia became transformed into single sporangia, filling the host cell completely. A dense, fine fibrillar sporangial wall was deposited onto the host cell wall (Figs. 31, 32). In contrast to cyst walls, sporangial walls showed no positive reaction to the chitin-binding protein (results not shown). The sporangia were not lobed. Two types of sporangia were observed: in one type, several small, vacuolate cells which did not produce zoospores became segregated at the apex (Figs. 32,34 ). The majority of sporangia (50 out of 57 ) was without these apical cells (Figs. 35, 36). Sporangia were oblong to club-shaped, those with apical cells often more ovoid. In E. siliculosus they were 40-93 $\mu \mathrm{m}$ in length and $27-46 \mu \mathrm{m}$ in diameter, in $\mathrm{E}$. fasciculatus they reached 20-155 $\mu \mathrm{m}$ in length and 15-60 $\mu \mathrm{m}$ in diameter. Sporangia showed peripheral aggregations of carotenoid granula and larger, spherical, brownish bodies (Figs. 35, 36). In both types of sporangia, the plasmodium cleaved into several hundred zoospores per sporangium (Figs. 31, 32, $35,36)$. Spore nuclei were without nucleoli, and the chromatin was condensed at the nuclear membrane. The two flagellar basal bodies were arranged in an angle of about $45^{\circ}$. They contained conspicuous globular material in their lumen (Fig. 33). Several mitochondria with tubular cristae and perinuclear Golgi bodies have been observed in zoospores prior to discharge (Fig. 31). The spores became vigorously motile while still inside the sporangium, and were released singly through an inconspicuous, narrow apical opening. Specialized exit tubes were not observed. According to electron microscopical evidence, the sporangial wall inside the host cell wall became at least partially degraded during spore release (not shown). The zoospores directly infected host cells in the manner described above. 


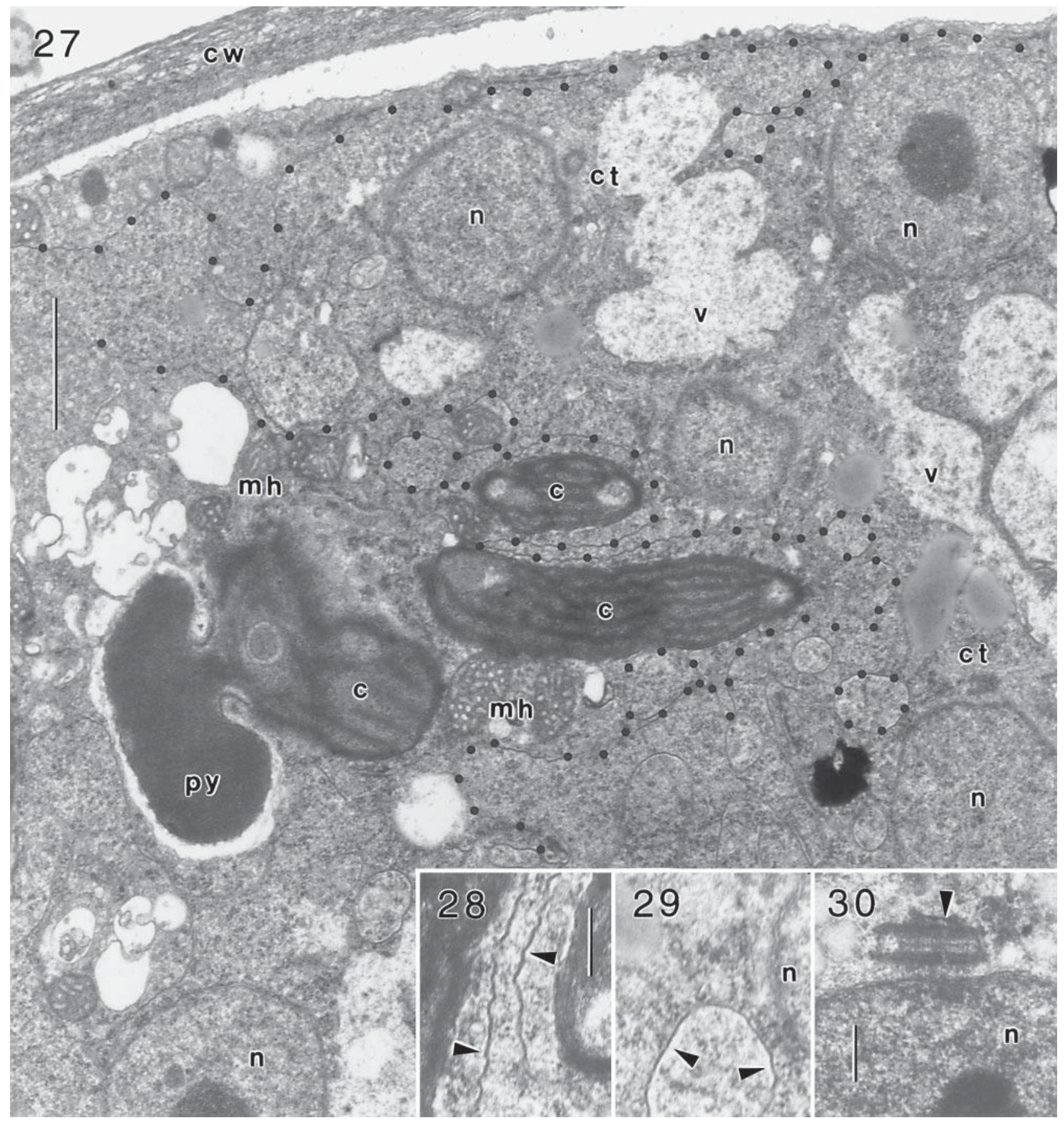

Figure 27. Electron micrograph of part of a plasmodium showing several parasite nuclei (n) with centrioles (ct), vacuoles with fibrillar content (v), and the host-parasite interphase (dots). Also visible are chloroplasts (c), a pyrenoid (py), mitochondria (mh) and the cell wall (cw) of the host. Scale bar $=1 \mu \mathrm{m}$.

Figure 28.

Figures 28, 29. Details of Fig. 27 showing the host-parasite boundary at higher magnification, in Fig. 29 close to a nucleus (n). Scale bar $=250 \mathrm{~nm}$.

Figure 30. An end-to-end joined pair of centrioles at one pole of the nucleus (n); the arrowhead points to the junction. Scale bar $=250 \mathrm{~nm}$. 


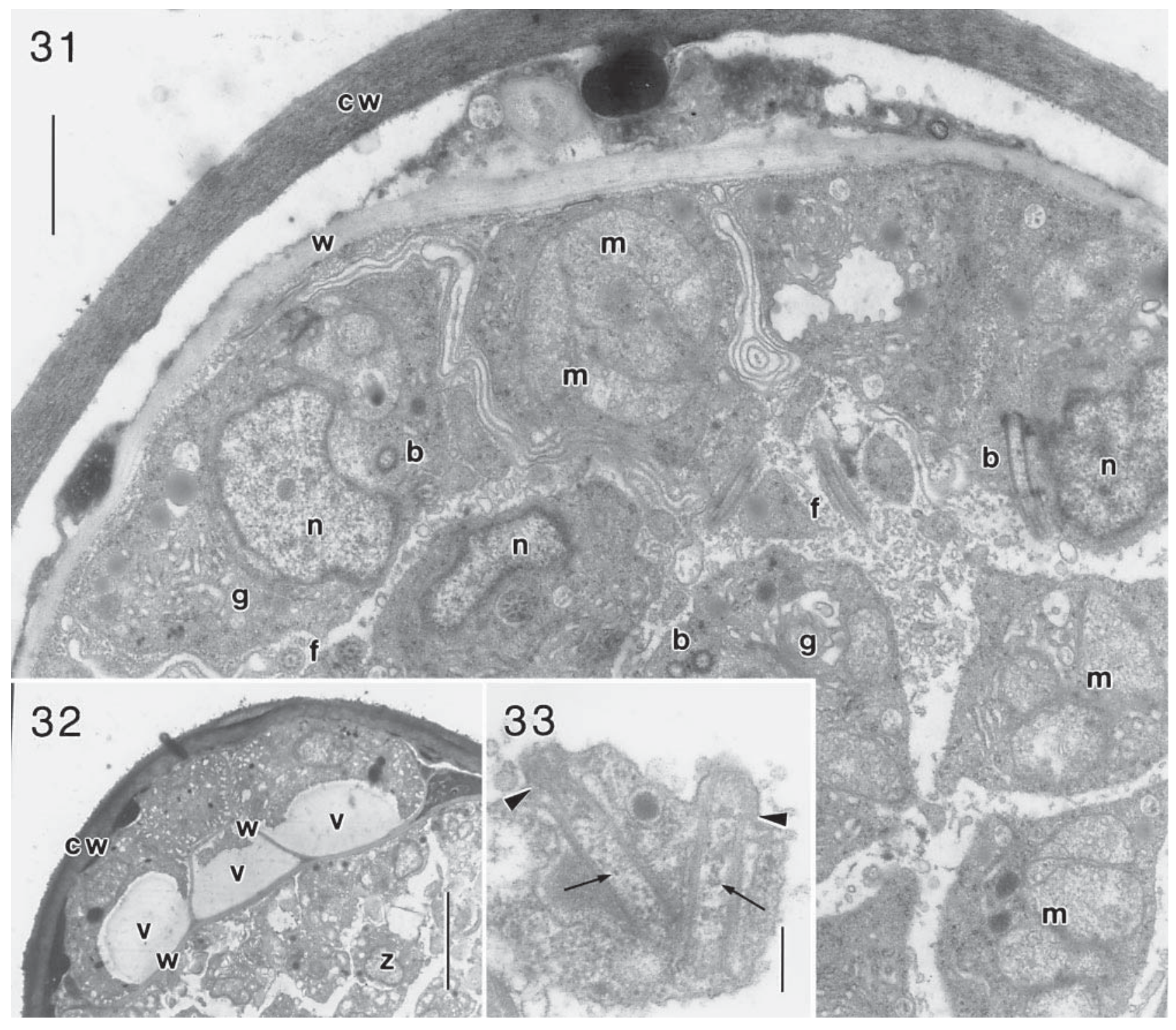

Figure 31. Section of a mature sporangium, showing the sporangium wall (w) within the host cell wall (cw) and zoospores with nuclei (n), mitochondria (m), Golgi (g), basal bodies (b), and flagellar profiles (f). Scale bar $=1 \mu \mathrm{m}$.

Figure 32. Electron micrograph showing a group of small cells with conspicuous vacuoles (v) at the apex of a sporangium with segregated zoospores (z). Also visible are the sporangium wall (w) and the host cell wall (cw). Scale bar $=5 \mu \mathrm{m}$.

Figure 33. Longitudinal section of both basal bodies of a zoospore within a sporangium. The arrowheads point to the transitional plate, the arrows to globular material inside the basal body lumen. Scale bar $=200 \mathrm{~nm}$.

\section{Infection Experiments}

In six independent experiments using infected $E$. fasciculatus filaments as a donor, the parasite returned to unialgal cultures of its original host, E. siliculosus. Additional infection experiments with various brown algal hosts demonstrated a broad host spectrum (Table 1, Figs. 37-40). Various filamentous species of different genera of the order Ec- tocarpales were subject to parasite attack. The studies also revealed that susceptibility to the parasite is independent of viral infection. The two types of parasite sporangia described above in E. siliculosus and $\mathrm{E}$. fasciculatus, have also been observed in Hincksia hincksiae (Harvey) Silva. In Hincksia mitchelliae (Harvey) Silva, the parasite also reproduced in non-hypertrophied filament cells (Fig. 38). Microscopic gametophytes of brown algae with hetero- 

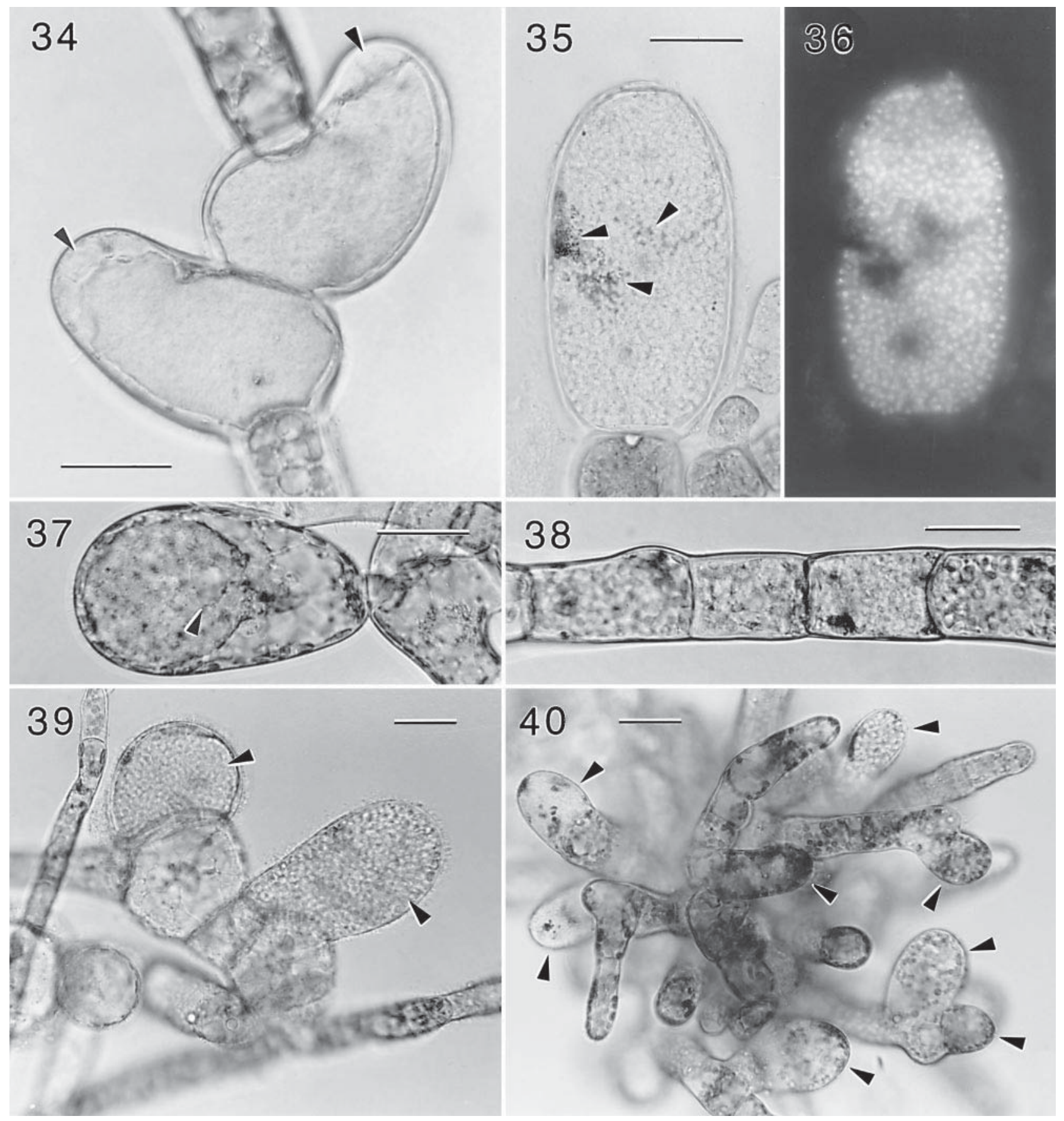

Figure 34. Immature sporangia of M. ectocarpii with group of apical cells (arrowheads) in the original host, E. siliculosus. Scale bar $=25 \mu \mathrm{m}$.

Figures $\mathbf{3 5}$ and 36. Mature sporangium without apical cells in E. siliculosus, DAPI staining showing numerous parasite nuclei stain. The sporangium contains large aggregations of carotenoid (arrowheads). Scale bar $=25 \mu \mathrm{m}$.

Figure 37. A plasmodium in Acinetospora crinita, enclosing the host cell nucleus (arrowhead). Scale bar $=25 \mu \mathrm{m}$.

Figure 38. Row of four intercalary parasite sporangia in a filament of Hincksia mitchelliae. Scale bar $=25 \mu \mathrm{m}$.

Figure 39. Mature sporangia (arrowheads) in gametophytes of Desmarestia munda. Scale bar $=25 \mu \mathrm{m}$.

Figure 40. Plasmodia and sporangia of M. ectocarpii in different developmental stages (arrowheads) in a female gametophyte of Macrocystis pyrifera. Scale bar $=25 \mu \mathrm{m}$. 
Table 1. Compatible host species in infection experiments.

\author{
Ectocarpales: \\ Acinetospora crinita, New Zealand \\ Feldmannia simplex, Ireland \\ Ectocarpus fasciculatus, France, with virus \\ E. siliculosus, Chile, original host \\ E. siliculosus, New Zealand \\ Hincksia hincksiae, France \\ H. mitchelliae, Argentina \\ H. mitchelliae, J apan \\ $H$. mitchelliae, USA \\ Kuckuckia spinosa, Norway
}

Scytothamnales:

Splachnidium rugosum, Tasmania

Desmarestiales:

Desmarestia munda, Canada

D. distans, Chile

Laminariales:

Macrocystis pyrifera, Chile

morphic life histories (Desmarestia and Macrocystis) also became infected (Figs. 39, 40). In all cases the morphological appearance of the parasite sporangia were similar to the situation in Ectocarpus: somatic filament cells hypertrophied and were transformed into sporangia of the parasite. In Macrocystis gametophytes, the parasite also entered young oogonia and thus reduced the host's reproductive potential. The size of sporangia varied somewhat in the different host species (Figs. 34-40). The development of the parasite required 16-40 days until obvious morphological infection symptoms appeared on various new hosts. Infection experiments with Bachelotia antillarum (Grunow) Gerloff were unsuccessful, since the parasite did not grow well at the temperature required for cultivation of the alga $\left(19{ }^{\circ} \mathrm{C}\right)$, and vice versa.

\section{Discussion}

The plasmodiophorids are probably a monophyletic group of uncertain phylogenetic affinity. The hitherto known species share the following characters: cruciform nuclear division, zoospores with two, anterior flagella of unequal length and without flagellar hairs, multinucleate protoplasts (plasmodia), obligate intracellular parasitism, and a complex life cycle. At present, 10 genera with a total of 35 species are recognized (Braselton 1995; Dylewski 1990).
Essential characters of the Ectocarpus parasite described here closely resemble those of the hitherto known plasmodiophorids. The plasmodia and sporangia observed in our study correspond to the primary or sporangial plasmodia and zoosporangia, respectively, in the generalized life cycle scheme as given by Braselton (1995). However, neither sporangiosori, nor sporogenic plasmodia or resting spores are formed. No evidence for sexuality was found. Zoospores, after encystment and host cell infection, develop directly into sporangial plasmodia. Compared to other plasmodiophorids, important parts of the life cycle (Braselton 1995) are apparently missing. The sporogenic phase may be completely absent. Possibilites for life cycle reduction are illustrated by other examples of the direct type of zoospore development (Braselton 1995) and by Ligniera betae (Nemec) Karling, in which a plasmodium may develop into a single zoosporangium without cleaving into segments and sporangiosorus formation (Karling 1968). On the other hand, it cannot be excluded that only part of the parasite's life cycle was observed in our study and that the sporogenic phase requires different culture conditions or a different host species. The significance of the occurrence of two structural types of zoosporangia is unknown, but is paralleled by the situation in Polymyxa graminis Ledingham. There, discharge of zoospores from sporangia is accomplished by small accessory cells which dissolve an opening into the host cell wall. These specialized cells are not present in all sporangia (Barr 1988).

Zoospore morphology is typical of plasmodiophorids. The arrangement of basal bodies before spore release is similar to that reported for Sorosphaera veronicae Schroeter (Talley et al. 1978) and in their structure they also resemble those in $\mathrm{P}$. graminis (Barr and Allan 1982). The formation of pseudopodia is in accordance with observations on zoospores of Plasmodiophora brassicae Woronin settled onto host cells, before encystment (Aist and Williams 1971). The infection apparatus (adhesorium) produced by cysts is strikingly similar to that in Polymyxa betae Keskin (Keskin and Fuchs 1969), P. graminis (Barr 1988) and P. brassicae (Aist and Williams 1971) and probably also to that in Woronina pythii Goldie-Smith (Dylewski 1990). The intracellular, tubular cavity observed in encysted zoospores probably corresponds to the "rohr", containing a harpoon- or bullet-shaped structure, the "stachel", which punctures the host cell wall before the parasite enters the host cell. The morphology of the adhesorium in the Ectocarpus parasite differs from that in the P. betae and P. brassicea in being pointed, instead of having a distal swelling. The infection appa- 
ratus shows certain analogies to the spectacular, harpoon-like attack apparatus in "gun cells" of the oomycete Haptoglossa mirabilis Barron, which infects rotifers (Robb and Barron 1982) and simple trichocysts in ciliates (Hausmann and Hülsmann 1996).

Parasite sporangia are often arranged in clusters. This coincides well with the growth pattern of Ectocarpus: mitoses are intercalary and frequently result in groups of a few neighbouring young cells within a given filament. Infection by the parasite may be restricted to such young host cells: either only cell walls of young cells can become penetrated by the parasite or some defense mechanism is effective in older cells. Clustering of infected cells may also result from induction of cell divisions in the vicinity of infected cells and formation of adventive lateral branches, which in turn become infected as well. Synchronous nuclear divisions are the consequence of the syncytical nature of the parasite. Occasional non-synchronous nuclear divisions in plasmodia probably originated form multiple infections in a single host cell. The occurrence of cruciform nuclear divisions in young sporangial plasmodia is consistent with the basic life cycle of plasmodiophorids, where this specific type of nuclear division occurs during growth, and non-cruciform mitoses later in sporangial development (B raselton 1995). Nutrition is of the absorptive type, phagotrophy as in Plasmodiophora, Woronina or Octomyxa (Buczacki 1983) has not been observed in our isolate. The host-parasite boundary is interpreted as a thickened unit membrane, presumably the plasma membrane of the parasite. It is very similar in appearance to that of Veronica persica Poir. and S. veronicae (Braselton and Miller 1975) but markedly thinner than the two appressed membranes in P. brassicae (Williams and McNabola 1970). End-to-end paired centrioles are common in plasmodiophorids (Braselton 1990; Braselton et al. 1975; Dylewski and Miller 1984; Garber and Aist 1979). The presence of chitin in cyst walls is in accordance to other observations on the occurrence of chitin in plasmodiophorids (Buczacki 1983; Dylewski 1990). The failure of chitin staining of sporangial walls is possibly due to impermeability of the intact algal cell wall to the chitinbinding protein and enzymatic degradation of the sporangial wall during spore release.

The infection experiments carried out were no more than a preliminary exploration of the parasite's host range. The scope was limited to semimicroscopic, filamentous brown algae. Though larger, compact species and representatives of other algal classes were not included in this survey, the results provide unequivocal evidence for a broad host spectrum and possibly a widespread distribution of the parasite on cold-temperate coasts. Particularly the relatively slow-growing gametophytes of Macrocystis and Desmarestia became heavily infested in culture. Macrocystis pyrifera (L.) C. Ag. is of high commercial importance, as are other species in the Laminariales. The pathogen could clearly have a devastating effect on gametophyte cultures used in mariculture facilities.

Some plasmodiophorids, in particular the plantinfecting species P. graminis, P. betae and Spongospora subterranea (Wallr.) Lagerh. are suspected of being important vectors of plant pathogenic viruses (Adams 1988; Arif et al. 1995; Brunt 1988; Teakle 1983). The transmitted viruses may simply be adsorbed to the surface of zoospores or are persistent within zoospores and dormant resting sporangia. A similar situation may be envisaged in brown algal viruses. Development of plasmodia in virusforming host cells has been observed in the present study. The occurrence of virions in zoospores of the parasite has not been demonstrated yet. Nevertheless it appears possible that brown algal viruses or virus DNA are transmitted during penetration of the algal cell wall and injection of the parasite into the host cytoplasm, especially in cases where further development of the parasite fails. By this mechanism the relatively narrow host ranges of the known brown algal viruses could be significantly expanded, and viral DNA could move within the broader host range of the plasmodiophorid.

Several plasmodiophorids have been recorded in heterokont hosts: Octomyxa achlyae Couch, Leitner et Whiffen, 0 . brevilegniae Pendergrass, Sorodiscus cokeri Goldie-S mith, Woronina polycystis Cornu and W. pythii parasitize various oomycetes, inducing enlargement of the infected portion (hypertrophy) and septation of hyphae (Karling 1968). Woronina glomerata (Cornu) Fischer develops within Vaucheria ssp. without causing hypertrophy, but septation of the host thallus (Zopf 1894).

Phagomyxa algarum, described by Karling (1944) as an endocytoplasmatic parasite in the brown algae Pylaiella fulvescens (Schousboe) Bornet (now Bachelotia antillarum (Grunow) Gerloff; Börgesen 1926; Dawes 1974) and Ectocarpus mitchellae Harvey (now Hincksia mitchelliae (Harvey) Silva; Silva et al. 1996) at Beaufort, North Carolina is, in many aspects, clearly different from our isolate. $\mathrm{H}$. mitchelliae (from Beaufort) has been included in our infection studies, as well as B. antillarum (from Sao Paulo, Brazil). In the latter species, the experiment has been unsuccessful because of diverging temperature optima of the host and the parasite. According to Karling (1944), the plasmodium of Phagomyxa is phagotrophic, has a large central vacuole, 
and does not or only slightly cause cellular hypertrophy of the infected cell. It cleaves at maturity and forms a sporangiosorus, with an individual opening for each sporangium through the cell wall. The zoospores do not encyst and enter the host as amoebae. The presence of cruciform nuclear divisons has not been clearly demonstrated. Phagomyxa shows amoeboid movement of plasmodia, which has not been observed in our material. Phagomyxa was found again by Schnepf (1994) in a different host, the centric marine diatom Bellerochea malleus (Brightwell) van Heurck from the Wadden Sea, German Bight. The fine structure of sporangia and zoospores, especially the flagellar apparatus, was found to correspond in important details to those of P. graminis (Barr and Allan 1982) and Ligniera verrucosa Maire and Tison (Miller et al. 1985). Phagomyxa was thus regarded by Schnepf (1994) a member of the Plasmodiophorea. The infection mechanism and mitoses as well as resting spores/ sporosori were not observed. Attempts to maintain the Bellerochea parasite in culture failed. Aguilera et al. (1988) described an endophytic parasite in subcortical cells of the brown alga Durvillaea antarctica (Cham.) Hariot from Chile and placed the unnamed parasite into the Plasmodiophorea. The parasite forms gall-like structures on the thallus. However, the structure and development of the parasite are insufficiently known and the placement into the plasmodiophorids appears rather questionable. All other known marine plasmodiophorids (Plasmodiophora ssp., Tetramyxa parasitica Goebel) are parasites of seagrasses and similar angiosperms, in particular Zostera, Halodule, Halophila, Ruppia, Zannichellia and Triglochin (Braselton 1990; den Hartog 1963, 1965; Luther 1949; Marziano et al. 1995; Porter 1986). Marine angiosperms, as mentioned above as potential hosts of plasmodiophorids, are not known from the Maullín estuary where the Ectocarpus parasite has been isolated.

The Ectocarpus parasite described in the present study is characterized by features specific for the plasmodiophorids, i. e. zoospore structure, the infection mechanism, obligate endoparasitism, syncytical development and cruciform nuclear divisions. The comparison with other plasmodiophorids is complicated by the lack of sporogenic plasmodia and sporosori, the morphologies of which are used to distinguish plasmodiophorid genera (Braselton 1995; Dylewski 1990). In T. parasitica and Plasmodiophora ssp., parasites of marine angiosperms, the sporangiogenous plasmodia, sporangia and zoospores are unknown and thus direct comparisons cannot be made. Absence of the sporogenic phase, i. e. presence of a direct-type life cycle, and non- lobed zoosporangia are the main features distinguishing the Ectocarpus parasite from other plasmodiophorids. In view of this, together with the other structural and developmental characters as well as the marine habitat and brown algae as hosts, the new parasite does not correspond to any of the known plasmodiophorid taxa. It is thus described as a new species, Maullinia ectocarpii, in a new genus, Maullinia.

\section{Diagnoses}

\section{Genus Maullinia I. Maier, E. R. Parodi, R. Wester- meier et D. G. Müller, genus novum}

Obligate intracellular parasite in marine brown algae (Phaeophyceae). Multinucleate unwalled syncytium (plasmodium) within host cell cytoplasm, gradually occupying the hypertrophied host cell, osmotrophic type of nutrition. Cruciform nuclear divisions at early developmental stage. No schizogony of plasmodia. Plasmodia become transformed into single sporangia, filling the host cell completely. Sporangial wall deposited onto the host cell wall. Sporangia not lobed. Plasmodium cleaves into numerous zoospores released singly through an apical opening. No conspicous release tubes formed. Zoospores pyriform, with two unequal, whiplash-type flagella inserted subapically on the broader part of the cell. Spores amoeboid, forming cysts with chitinous walls upon settlement. Infection of host cells by means of an adhesorium and a stachel apparatus penetrating the host cell wall. Cyst content injected into host cell cytoplasm.

Sexual reproduction and resting spores unknown. Type species: Maullinia ectocarpii I. Maier, E. R. Parodi, R. Westermeier et D. G. Müller sp. nov.

Etymology: The name refers to the geographic origin of the type species

- Maullinia ectocarpii I. Maier, E. R. Parodi, R. Westermeier et D. G. Müller species novum

Characters of the genus. Infecting Ectocarpus and other marine filamentous Phaeophyceae. Zoospores $4.6 \pm 0.7 \mu \mathrm{m}$ in length and $2.3 \pm 0.4 \mu \mathrm{m}$ in diameter. Posterior flagellum $19.3 \pm 1.7 \mu \mathrm{m}$, anterior flagellum $8.2 \pm 0.6 \mu \mathrm{m}$ in length. Cysts ellipsoid, $5.8 \pm 0.7 \mu \mathrm{m}$ in length and $2.5 \pm 0.2 \mu \mathrm{m}$ in diameter. Adhesorium pointed, 5-7 $\mu \mathrm{m}$ long and 0.8-1.2 $\mu \mathrm{m}$ in diameter, connected to the cell body by a narrow neck portion of about $0.8 \mu \mathrm{m}$ in length. Sporangia oblong to club-shaped and, in Ectocarpus, 20-155 $\mu \mathrm{m}$ in length and 15-60 $\mu \mathrm{m}$ in diameter. 
Etymology: The specific epithet refers to the host genus, Ectocarpus.

Holotype: Permanent microslide from a co-culture of the parasite and the host Ectocarpus fasciculatus Harvey from Roscoff, France, prepared on February 1st, 2000 and deposited in the herbarium of the of the Natural History Museum (BM), London (registration number: 2000:2:29:1).

Isotypes: Same material as holotype, on permanent slides, deposited in the herbaria of the Natural History Museum, London (BM; registration numbers: 2000:2:29:2, :3), the Muséum National d Histoire Naturelle, Paris ( $\mathrm{PC})$, the Botanical Museum, University of Copenhagen ( $C$; accession numbers A-type 1886-1888), the University of California, Berkeley (UC; registration numbers: 1726330 and 1726331), and the Museo Nacional de Historia Natural, Santiago de Chile (SGO). Cultures are available from the author's culture collection.

\section{Methods}

Algal material: The Universidad Austral de Chile maintains an experimental mariculture plantation of Gracilaria chilensis at La Pasada in the estuary of the Maullín river near Puerto Montt, Chile $\left(41^{\circ} 40\right.$ 'S, $73^{\circ} 45 \mathrm{~W}$ ). At this site, the salinity may fluctuate between 7 and $28 \%$, depending on season and tide. The water temperature ranges between about $10{ }^{\circ} \mathrm{C}$ in July and $16-20^{\circ} \mathrm{C}$ in December. Ectocarpus specimens 1 to $2 \mathrm{~cm}$ in length, growing epiphytically on Gracilaria in the lower intertidal were collected on December 26, 1996. Most of the Ectocarpus thalli were fertile with plurilocular sporangia. Some, however, were sterile and formed clusters of unpigmented, grossly swollen cells. Fragments of such Ectocarpus filaments were used to initiate crude cultures and successive elimination of contaminants resulted in the establishment of unialgal cultures still maintaining the unusual structures seen in the field material. In parallel, we established a subclone of the host from a thallus fragment without the parasite.

Based on the lack of the betaine lipid DGTA as a chemotaxonomic marker (Müller and Eichenberger 1995) the original host was identified as E. siliculosus (Dillwyn) Lyngbye. Detection of a virus-specific DNA sequence by PCR amplification (Sengco et al. 1996) showed that the host carried a latent virus infection. This was confirmed by the occasional appearance of the catenate modified sporangia typical for virus infection (Müller et al. 1998).

Culture conditions: Cultures were kept at $12{ }^{\circ} \mathrm{C}$ in autoclaved artificial seawater (hw Meersalz pro- fessional; Wiegandt GmbH, Krefeld, Germany) supplemented by Provasoli's seawater enrichment (Provasoli 1968). Cultures were maintained in $60 \mathrm{~mm}$ plastic Petri dishes and illuminated with daylight type fluorescent lamps at $20 \mu \mathrm{mol} \mathrm{m} \mathrm{m}^{-2} \mathrm{~s}^{-1}$ for $14 \mathrm{~h}$ per day. Transfer to fresh culture medium was done at one or bi-weekly intervals.

Infection experiments: Ectocarpus filaments with one or two clusters of mature parasite sporangia were incubated with clonal cultures of various potential host species for several days or weeks. The new hosts were examined for the development of pathological symptoms by light microscopy. The following isolates were used as recipients in infection experiments: Acinetospora crinita (Carmichael) Kornmann, Kaikoura, New Zealand 1988; Bachelotia antillarum (Grunow) Gerloff, Sao Paulo, B razil 1996; Desmarestia munda Setchell and Gardner, female gametophyte, Bamfield, BC, Canada 1985; D. distans (C. Agardh) J. Agardh, gametophyte, Punta Arenas, Magellan Strait, Chile 1988; Ectocarpus fasciculatus Harvey, sporophyte, infected by virus, Roscoff, France 1993 (Parodi and Müller 1994); E. siliculosus (Dillwyn) Lyngbye: (a) original host, virusinfected, sporophyte, Maullín, Puerto Montt, Chile 1996; (b) female gametophyte, Kaikoura, New Zealand 1988 (Sengco et al. 1996); (c) male gametophyte, virus-infected, dto.; Feldmannia simplex (Crouan) Hamel, Aran Islands, Ireland 1990; Hincksia hincksiae (Harvey) Silva, Roscoff, France 1993 (Parodi and Müller 1994); H. mitchelliae (Harvey) Silva: (a) Las Grutas, Argentina 1995; (b) Inland Sea, J apan 1993; (c) gametophyte, Beaufort, NC, USA; Kuckuckia spinosa (Kuetzing) Kornmann; Bergen, Norway 1989; Macrocystis pyrifera (Linneaus) C. Agardh, female gametophyte, Fuerte Bulnes, Magellan Strait, Chile 1989; Splachnidium rugosum (Linneaus) Greville, Tasmania 1984. All algal strains used in the infection experiments were own isolates collected on the sites given above and kept in clonal unialgal culture.

Microscopy: Zoospores were fixed in $\mathrm{OsO}_{4}$ vapour for photography. For DAPI staining, algal filaments were fixed with $2.5 \%$ glutaraldehyde in $90 \%$ culture medium for $1 \mathrm{~h}$, washed four times with seawater for 10 min each and then incubated with DAPI ( $2 \mathrm{\mu g} \mathrm{ml}^{-1}$ in seawater) for $2 \mathrm{~h}$. Nuclear staining using Wittmann's chloral hydrate-haematoxylin method (Wittmann 1965) was carried out after fixation in ethanol/acetic acid ( $3: 1)$. After staining, permanent slides were made by transfer into $96 \%$ ethanol and subsequent embedding in Euparal (Chroma Gesellschaft, Schmid GmbH, Köngen, Germany). For chitin staining, algal filaments were fixed in ethanol/ acetic acid (3:1). An FITC-conjugated recombinant 
chitin-binding protein (FUNGALASE ${ }^{\mathrm{TM}}-\mathrm{F}$, Anomeric, Baton Rouge, USA) was applied according to the manufacturer's protocol, but omitting the periodic acid oxidation step. The specimens were mounted in SLOWFADE-LIGHT antifade solution (MoBiTec, Göttingen, Germany). Photographs were taken on IIford 400 ASA HP5 Plus film (fluorescence) and Kodak 50 ASA Technical Pan film (bright field and phase contrast). Electron microscopy was carried out on the original host using standard protocols (Parodi and Müller 1994). Type material was fixed with $2.5 \%$ glutaraldehyde in $90 \%$ culture medium, stained with $1 \%$ aq. aniline blue and mounted in KARO ${ }^{\circledR}$ corn syrup.

\section{Acknowledgements}

This work was partially supported by FONDECYT grants 0219-90 and 1951203-1995 to R. W. and a DAAD travel grant to D. G. M.

\section{References}

Adams MJ (1988) Evidence for virus transmission by plasmodiophorid vectors. In Cooper JI, Asher MJC (eds) Developments in Applied Biology 2: Viruses with Fungal Vectors. Association of Applied Biologists, Wellesbourne, Warwick, pp 203-211

Aguilera M, Rivera PJ , Westermeier R (1988) Presencia de hongos Plasmodiophorales en plantas de Durvillaea antarctica (Cham.) Hariot (Phaeophyta, Durvillaeaceae) del sur de Chile. Gayana, Bot 45: 337-343

Aist J R, Williams PH (1971) The cytology and kinetics of cabbage root hair penetration by Plasmodiophora brassicae. Can J Bot 49: 2023-2034

Andrews J H (1976) The pathology of marine algae. Biol Rev. 51: 211-253

Arif M, Torrance L, Reavy B (1995) Acquisition and transmission of potato mop-top furovirus by a culture of Spongospora subterranea f. sp. subterranea derived from a single cystosorus. Ann appl Biol 126: 493-503

Barr DJ S (1988) Zoosporic plant parasites as fungal vectors of viruses: taxonomy and life cycles of species involved. In Cooper J I, Asher MJ C (eds) Developments in Applied Biology 2: Viruses with Fungal Vectors. Association of Applied Biologists, Wellesbourne, Warwick, pp 123-137

Barr DJ S (1992) Evolution and kingdoms of organisms from the perspective of a mycologist. Mycologia 84: 1-11

Barr DJ S, Allan PME (1982) Zoospore ultrastructure of Polymyxa graminis (Plasmodiophoromycetes). Can J Bot 60: 2496-2504
Börgesen F (1926) Marine algae from the Canary Islands. Det Kung Danske Videnskab Selskab Biol Medd 6: 1-112

Braselton J P (1990) Ultrastructure and karyology of Tetramyxa parasitica (Plasmodiophoromycetes). Can J Bot 68: 594-598

Braselton J P (1995) Current status of the plasmodiophorids. Crit Rev Microbiol 21: 263-275

Braselton J P, Miller CE (1975) Host-parasite interface of Veronica persica and Sorosphaera veronicae (Plasmodio phoromycetes). Arch Microbiol 104: 97-99

Braselton J P, Miller CE, Pechak DG (1975) The ultrastructure of cruciform nuclear division in Sorosphaera veronicae (Plasmodiophoromycetes). Amer J Bot 62: 349-358

Brunt AA (1988) Labile rod-shaped viruses transmitted by plasmodiophorid fungi: furoviruses. In Cooper JI, Asher MJ C (eds) Developments in Applied Biology 2: Viruses with Fungal Vectors. Association of Applied Biologists, Wellesbourne, Warwick, pp 3-17

Buczacki ST (1983) Plasmodiophora. An inter-relationship between biological and practical problems. In Buczacki ST (ed) Zoosporic plant pathogens. A modern perspective. Academic Press, London, pp 161-191

Castlebury LA, Domier, LL (1998) Small subunit ribosomal RNA gene phylogeny of Plasmodiophora brassicae. Mycologia 90: 102-107

Cavalier-Smith T (1993a) Kingdom Protozoa and its 18 phyla. Microbiol Rev 57: 953-994

Cavalier-Smith T (1993b) The protozoan phylum Opalozoa. J Euk Microbiol 40: 609-615

Corliss J 0 (1994) An interim utilitarian ("user-friendly") hierarchical classification and characterization of the protists. Acta Protozool 33: 1-51

Dawes CJ (1974) Marine algae of the west coast of Flo rida. University of Miami Press, Coral Gables, Florida den Hartog C (1963) Tetramyxa parasitica, een gal op Ruppia. Gorteria 1: 138-140

den Hartog C (1965) Some notes on the distribution of Plasmodiophora diplantherae, a parasitic fungus on species of Halodule. Persoonia 4: 15-18

Dylewski DP (1990) Phylum Plasmodiophoromycota. In Margulis L, Corliss J O, Melkonian M, Chapman DJ (eds) Handbook of Protoctista. J ones and Bartlett Publ, Boston, pp 399-416

Dylewski DP, Miller CE (1984) The ultrastructure of mitosis during sporangiogenesis in Woronina pythii (Plasmodio phoromycetes). Protoplasma 121: 42-53

Dylewski DP, Braselton J P, Miller CE (1978) Cruciform nuclear division in Sorosphaera veronicae. Amer J Bot 65: 258-267

Garber RC, Aist J R (1979) The ultrastructure of mitosis in Plasmodiophora brassicae (Plasmodiophorales). J Cell Sci 40: 89-110 
Hausmann K, Hülsmann N (1996) Protozoology, 2nd ed. Thieme, Stuttgart.

Karling J S (1944) Phagomyxa algarum n. gen. n. sp., an unusual parasite with plasmodiophoralean and proteomyxean characteristics. Am J B ot 31: 38-52

Karling J S (1968) The Plasmodiophorales. 2nd Ed. Hafner Publishing Company, New York

Karling J S (1981) Woronina leptolegniae n. sp., a plasmodiophorid parasite of Leptolegnia. Nov Hedw 35: $17-24$

Keskin B (1971) Beitrag zur Promitose bei Polymyxa betae Keskin. Arch Mikrobiol 77: 344-348

Keskin B, Fuchs WH (1969) Der Infektionsvorgang bei Polymyxa betae. Arch Mikrobiol 68: 218-226

Küpper FC, Müller DG (1999) Massive occurrence of the heterokont and fungal parasites Anisolpidium, Eurychasma and Chytridium in Pylaiella littoralis (Ectocarpales, Phaeophyceae). Nov Hedw 69: 381-389

Luther H (1949) Beobachtungen über Tetramyxa parasitica Goebel. Mem Soc Fauna Flora Fenn 25: 88-96

Marziano F, Villari R, Tripodi G (1995) A plasmodiophorid fungal parasite of the seagrass Halophila stipulacea. Mycotaxon 55: 165-170

Miller CE, Martin RW, Dylewski DP (1985) The ultrastructure of plasmodia, sporangia, and cystosori of Ligniera verrucosa (Plasmodiophoromycetes). Can J Bot 63: 263-273

Müller DG, Eichenberger W (1995) Crossing experiments, lipid composition, and the species concept in Ectocarpus siliculosus and E. fasciculatus (Phaeophyceae, Ectocarpales). J Phycol 31: 173-176

Müller DG, Kapp M, Knippers R (1998) Viruses in marine brown algae. Adv Virus Res 50: 49-67

Müller DG, Küpper FC, Küpper H (1999) Infection experiments reveal broad host ranges of Eurychasma dicksonii (Oomycota) and Chytridium polysiphoniae (Chytridiomycota), two eukaryotic parasites in marine brown algae (Phaeophyceae). Phycol Res 47: 217-223

Parodi ER, Müller DG (1994) Field and culture studies on virus infections in Hincksia hincksiae and Ectocarpus fasciculatus (Ectocarpales, Phaeophyceae). Eur J Phycol 29: 113-117
Porter D (1986) Mycoses of marine organisms: an overview of pathogenic fungi. In Moss ST (ed) The biology of marine fungi. Cambridge University Press, Cambridge, pp 141-153

Provasoli L (1968) Media and prospect for the cultivation of marine algae. In Watanabe A, Hattori A (eds) Cultures and collections of algae. Proceedings of the U.S.J apan Conference 1966, Hakone. J apanese Society for Plant Physiology, pp 63-75

Robb E, Barron GL (1982) Nature's ballistic missile. Science 218: 1221-1222

Schnepf E (1994) A Phagomyxa-like endoparasite of the centric marine diatom Bellerochea malleus: a phagotrophic plasmodiophoromycete. Bot Acta 107: 374-382

Sengco MR, Bräutigam M, Kapp M, Müller DG (1996) Detection of virus DNA in Ectocarpus siliculosus and $E$. fasciculatus (Phaeophyceae) from various geographic areas. Eur J Phycol 31: 73-78

Silva PC, Basson PW, Moe RL (1996) Catalogue of the benthic marine algae of the Indian Ocean. University of California Press, Berkeley

Sparrow FK (1960) Aquatic phycomycetes. University of Michigan Press, Ann Arbor

Talley MR, Miller CE, Braselton J P (1978) Notes on the ultrastructure of zoospores of Sorosphaera veronicae. Mycologia 70: 1241-1247

Teakle DS (1983) Zoosporic fungi and viruses - double trouble. In Buczacki ST (ed) Zoosporic plant pathogens. A modern perspective. Academic Press, London, pp 233-248

Williams PH, McNabola SS (1970) Fine structure of the host-parasite interface of Plasmodiophora brassicae in cabbage. Phytopathology 60: 1557-1561

Wittmann W (1965) Aceto-iron-haematoxylin-chloral hydrate for chromosome staining. Stain Technol. 40: 161-164

Zopf W (1894) Ueber niedere thierische und pflanzliche Organismen, welche als Krankheitserreger in Algen, Pilzen, niederen Thieren und höheren Pflanzen auftreten. Beitr Physiol Morph Niederer Organismen 2: 43-68, plates II and III 